\title{
Genetic diversity in ornamental pepper plants
}

\author{
Flávia Laís Gomes Fortunato*, Elizanilda Ramalho do Rêgo, Michelle Gonçalves de Carvalho, \\ Cristine Agrine Pereira dos Santos, Mailson Monteiro do Rêgo
}

Federal University of Paraiba, Areia, Brazil

*Corresponding author, e-mail: fllavia.lais@gmail.com

\begin{abstract}
The genus Capsicum comprises a wide variety of peppers and peppers, with different sizes, colors and flavors. The present work had the objective to characterize and evaluate the genetic divergence among eight accessions of pepper (Capsicum annuum). The experiment was developed at the Federal University of Paraíba, Areia - PB. Eight accessions of pepper belonging to the germplasm bank of the CCA-UFPB were used. The experimental design was completely randomized. Data were submitted to analysis of variance by the F test at a level of $5 \%$ and $1 \%$ significance and the means were grouped by the Scott Knott test at $5 \%$ and $1 \%$ significance. For the analysis of genetic divergence, the Tocher grouping method and canonical variables were used. The treatment effects were significant, by the $\mathrm{F}$ test, at a level of $1 \%$ for all the characteristics evaluated, except for crown width and stem diameter, which were significant at $5 \%$ probability. According to the results obtained in the Scott \& Knott test at $5 \%$ and $1 \%$ probability, the accessions were differentiated into two to six different classes. According to Tocher's methodology the accessions were grouped into two groups. In the analysis of the canonical variables, the first three variables explained $94.18 \%$ of the total variance, and four different groups were formed according to the graphical dispersion.
\end{abstract}

Keywords: Capsicum annuum, genetic variability, breeding

\section{Introduction}

The genus Capsicum comprises a highly diversified group of peppers and bell peppers (Pickersgill, 1997). Currently, the species of this genus are consumed by a quarter of the world population, and present a highly diversified market, extending from the commercialization for in natura consumption and homemade canned sauces to the exportation of industrialized products. It is utilized in pharmaceutical and cosmetic products, besides its use as ornamental plants (Ferrão et al., 2011; Ferraz et al., 2016; Neitzke et al., 2016).

An outstanding factor for the ornamental use of Capsicum is its ability to grow in containers as a perennial plant, besides being of easy cultivation and great durability (Neitzke et al., 2010; Neitzke et al., 2016). Peppers also present characteristics of high aesthetical value, such as color and fruit position, leaf density and the plant architecture. The preference isfor small size and compact plants and with colored and erect fruits. In addition the resistant genotypes to diseases and plagues are desired (Neitzke et al., 2016; Rêgo et al., 2009a; Rêgo et al., 2012a). The easy propagation through seeds, the relatively short time for cultivation, and the tolerance to heat and drought also contribute to its utilization as ornamental plant (Rêgo et al., 2012a).

Ornamental pepper plants present 
importance in income generation for small farmers (Rêgo et al. 2015; Rêgo \& Rêgo 2016; 2018). The characterization and evaluation of conserved genotypes constitute a step of great importance for the immediate utilization of the species in breeding programs (Costa et al., 2015; Ferraz et al., 2016; Rêgo et al., 2011). It is fundamental the detection of duplicate plants in the germplasm banks (Gonçalves et al., 2008; Laurentin, 2009; Rêgo et al., 2011). Trustworthy methods and processes for the characterization of the germplasm are indispensable for increasing the use of the available variability (Silva et al., 2013).

The morpho-agronomic characterization is performed based on easy-measurement characters, with high heritability, and little environmental influence. For the genus Capsicum, this characterization is based on the descriptors list of the Biodiversity International, previous International Plant Genetic Resources Institute (IPGRI, 1995) (Costa et al., 2009; Silva et al., 2013).

The present work had as objective to characterize and to evaluate the genetic diversity within eight pepper accessions (Capsicum annuum) of the germplasm bank of the CCA-UFPB, based on 21 quantitative plant and fruit characters.

\section{Material and methods}

The present work was developed in a plant nursery belonging to the Laboratory of Vegetal Biotechnology of the Center of Agrarian Sciences of the Federal University of Paraíba (CCA-UFPB), Areia - PB state. Seeds from eight pepper accessions belonging to the germplasm bank of the CCA-UFPB were utilized: (UFPB 346, UFPB 347, UFPB 348, UFPB 349, UFPB 352, UFPB 355, UFPB 356 and UFPB 357), previously selected by presenting contrasting and multiple coloring flowers, fruits and leaves.

The seeds were sown in polystyrene trays with 128 cells, utilizing a commercial substrate (Plantmax®) and 2 to 3 seeds per cell. When the seedlings presented four definitive leaves, the trasplanting was performed, followed afterwards of the transplantation to $900 \mathrm{~mL}$ plastic containers, containing the same cited substrate.
The experimental design was completely randomized, with five replicates per accession.

The morpho-agronomic characterization was performed based on the list of descriptors suggested by the Biodiversity International (IPGRI, 1995), with 21 quantitative characters being evaluated as to the plant, inflorescence and fruit. The characters concerning the plants were evaluated when these presented the first mature fruit. The following descriptors were utilized: canopy width ( $\mathrm{CW})$, plant height $(\mathrm{PH})$, first bifurcation height (FBH), stem diameter (SD), leaf length (LL), petiole length (PL) and leaf width (LW). When the plants presented $50 \%$ of flowering, the following quantitative descriptors were utilized: corolla length (CL), petal diameter (PD), anther length (AL) and filament length $(F L)$. The descriptors referring to the fruit were evaluated when the plant presented $50 \%$ of mature fruits. These descriptors were: fruit weight (FrW), fruit length (FrL), largest fruit diameter (LFD), smallest fruit diameter (SFD), peduncle length (PL), pericarp thickness (PT), placenta length (PIL), number of seeds/fruit (NSF), fresh matter (FM) and dry matter content (DMC). The descriptors regarding length, width and thickness were measured with a digital pachymeter, and the weight descriptors were measured by utilizing a precision balance.

The data were subjected to analysis of variance by the $\mathrm{F}$ test at $5 \%$ and $1 \%$ levels of significance, and the means were grouped by the Scott Knott test at $5 \%$ and $1 \%$ significance. For the analysis of genetic diversity, Tocher's grouping method was utilized, based on the generalized Mahalanobis distance and canonical variables. The relative importance of the characteristics was calculated based on the method proposed by SINGH (1981) and by the analysis of the canonical variables. The statistical analyses were performed by utilizing the software Genes (Cruz, 2006).

\section{Results and discussion}

The treatment effects were significant by the $\mathrm{F}$ test at $1 \%$ probability for all evaluated characteristics, with exception to the canopy width and stem diameter, which were significant at $5 \%$ (Table 1). These results point to the existence 
of genetic variability and to the possibility of obtaining genetic gains to these characteristics in future breeding works with these species (Ferrão et al., 2011). Costa et al. (2016), working with Capsicum, described significant differences at $5 \%$ probability for almost all evaluated characteristics, excepting plant height, stem diameter and dry matter content. Pessoa et al.
(2015) and Silva Neto et al. (2014) also reported significant differences for almost all evaluated variables in segregating populations of Capsicum annuum, thus evidencing the presence of genetic diversity within the families, emphasizing the need to perform studies, not only within the families but also among the families.

Table 1. Summary of the analysis of variance for twenty-one characters of pepper plant (Capsicum annuum).

\begin{tabular}{|c|c|c|c|c|c|c|c|}
\hline \multirow{2}{*}{ S.V } & \multicolumn{7}{|c|}{ Mean square } \\
\hline & $\mathrm{CW}$ & ph & fbh & sd & $\|$ & $\mathrm{pl}$ & IW \\
\hline treatment & $18.3166^{*}$ & $195.5585^{* *}$ & $85.3142^{* *}$ & $0.0461^{*}$ & $5.2081^{* *}$ & $1.1557^{* *}$ & $2.3023^{* *}$ \\
\hline general mean & 20.6600 & 23.3575 & 10.2475 & 0.6955 & 4.7480 & 1.9597 & 2.2715 \\
\hline C.V. & 12.0892 & 13.7720 & 24.0708 & 17.6059 & 13.4584 & 25.7242 & 14.7179 \\
\hline \multirow{2}{*}{ S.V } & \multicolumn{7}{|c|}{ Mean square } \\
\hline & $\mathrm{Cl}$ & pd & al & fl & frw & $\mathrm{frl}$ & Ifd \\
\hline treatment & $0.4926^{* *}$ & $0.0732^{* *}$ & $0.0263^{* *}$ & $0.0665^{* *}$ & $26.7242^{* *}$ & $9.8615^{* *}$ & $1.8704^{* *}$ \\
\hline general mean & 1.3362 & 0.4615 & 0.3177 & 0.4055 & 2.1817 & 2.5145 & 1.2342 \\
\hline C.V. & 13.3452 & 16.4130 & 10.8593 & 12.6199 & 34.8850 & 10.9010 & 9.1977 \\
\hline \multirow{2}{*}{ S.V } & \multicolumn{7}{|c|}{ Mean square } \\
\hline & sfd & $\mathrm{pl}$ & pt & pll & nsf & $\mathrm{fm}$ & dmc \\
\hline treatment & $0.7019^{* *}$ & $0.4966^{* *}$ & $0.0247^{* *}$ & $4.204^{* *}$ & $1440.318^{* *}$ & $20.1341^{* *}$ & $236.978^{* *}$ \\
\hline general mean & 0.8042 & 1.9170 & 0.1575 & 1.6687 & 33.6795 & 1.8255 & 18.5829 \\
\hline C.V. & 15.0898 & 6.9578 & 16.1484 & 13.7162 & 41.0814 & 32.2282 & 16.6840 \\
\hline
\end{tabular}

The coefficients of variation (CV) of the experiment varied from $6,96 \%$ (PL) to $41,08 \%$ (NSF) (Table 1), being these values considered satisfactory, since significant differences were detected within the evaluated accessions. According to Silva et al. (2011), the CV values vary according to the characteristic, with the accession and with the evaluated species.

According to the results obtained in the Scott \& Knott test at $5 \%$ and at $1 \%$ of probability (Table 2), the accessions were differentiated into two distinct classes regarding the canopy width, stem diameter and petiole length, presenting little variability for these characteristics. As to the first bifurcation height, petal diameter, filament length, fruit weight, smallest fruit diameter, pericarp thickness, number of seeds per fruit and dry matter content, three distinct classes were formed. For the plant height, leaf length, leaf width, corolla length, anther length, peduncle length, placental length and fresh matter, the accessions were differentiated into four classes. The characteristics that presented highest diversity were the fruit length and the largest fruit diameter, forming six distinct classes (Table 2).
According to Bianchi et al. (2016) and Neitzke et al. (2010), the large number of stablished classes is an indicative of the large existing variability within the accessions. This variability is important for the selection of genotypes with ornamental potential, such as lower size plants, with smaller fruits and more attractive flowers.

The values of canopy width varied from 18,38 to $21 \mathrm{~cm}$, with the accessions 348 and 349 being the ones with narrower canopy. As to the accessions 352 and 346, these presented the widest canopies, with means of 23,9 and $22,8 \mathrm{~cm}$, respectively (Table 2). According to Silva Neto et al. (2014) the ideal canopy width for ornamental pepper potted plants would be from 24 to $27 \mathrm{~cm}$ when in pots with $16 \mathrm{~cm}$ of width. In the same manner, Barroso et al. (2012) reported that the plant height and the canopy width ought to have from 1,5 to 2 times the size of the height and width of pot, respectively, in order to maintain the harmony between the plant architecture and the vase size. Since the pot width utilized in this study was $15,5 \mathrm{~cm}$, the widths of all studied accessions are within the preconized as ideal for ornamental pepper plants. 
Table 2. Means of twenty-one characters of pepper plant (Capsicum annuum) belonging to the germplasm bank (BAG)

\begin{tabular}{|c|c|c|c|c|c|c|c|}
\hline accessions & $\mathrm{CW}$ & ph & fbh & sd & $\pi$ & $\mathrm{p}$ & TW \\
\hline 346 & $22.80 \mathrm{a}$ & $21.20 \mathrm{C}$ & $6.38 \mathrm{c}$ & $0.904 a$ & $6.76 a$ & $2.73 a$ & $3.53 \mathrm{a}$ \\
\hline 347 & $20.00 \mathrm{~b}$ & $36.12 \mathrm{a}$ & $17.14 \mathrm{a}$ & $0.712 b$ & $5.63 b$ & $2.38 a$ & $2.62 \mathrm{~b}$ \\
\hline 348 & $18.38 \mathrm{~b}$ & $16.28 d$ & $5.26 \mathrm{C}$ & $0.652 \mathrm{~b}$ & $4.34 \mathrm{C}$ & $1.37 \mathrm{~b}$ & $2.04 \mathrm{C}$ \\
\hline 349 & $18.58 \mathrm{~b}$ & $18.48 \mathrm{~d}$ & $5.74 \mathrm{C}$ & $0.580 \mathrm{~b}$ & $4.45 \mathrm{C}$ & $1.81 \mathrm{a}$ & $2.15 \mathrm{C}$ \\
\hline 352 & $23.90 \mathrm{a}$ & $24.82 \mathrm{c}$ & $11.66 \mathrm{~b}$ & $0.716 b$ & $4.55 \mathrm{c}$ & $1.30 \mathrm{~b}$ & $2.74 \mathrm{~b}$ \\
\hline 355 & $21.00 \mathrm{~b}$ & $27.70 \mathrm{~b}$ & $12.20 \mathrm{~b}$ & $0.640 \mathrm{~b}$ & $4.80 \mathrm{C}$ & $1.95 \mathrm{a}$ & $1.98 \mathrm{C}$ \\
\hline 356 & $20.66 b$ & $21.98 \mathrm{C}$ & $12.56 \mathrm{~b}$ & 0.708 b & $3.95 d$ & $1.97 \mathrm{a}$ & $1.83 \mathrm{C}$ \\
\hline 357 & $20.00 \mathrm{~b}$ & $20.28 c$ & $11.04 \mathrm{~b}$ & $0.652 \mathrm{~b}$ & $3.51 \mathrm{~d}$ & $2.17 \mathrm{a}$ & $1.29 \mathrm{~d}$ \\
\hline accessions & $\mathrm{Cl}$ & $\mathrm{pd}$ & al & $f$ f & frw & $\mathrm{frl}$ & d \\
\hline 346 & $1.88 \mathrm{a}$ & $0.59 \mathrm{a}$ & $0.45 a$ & $0.53 \mathrm{a}$ & $6.89 \mathrm{a}$ & $4.11 \mathrm{~b}$ & $2.00 \mathrm{a}$ \\
\hline 347 & $1.22 \mathrm{C}$ & $0.45 \mathrm{~b}$ & $0.30 \mathrm{c}$ & $0.30 \mathrm{c}$ & $0.64 \mathrm{c}$ & $1.10 \mathrm{e}$ & $1.10 \mathrm{~d}$ \\
\hline 348 & $1.45 \mathrm{~b}$ & $0.57 \mathrm{a}$ & $0.37 \mathrm{~b}$ & $0.38 \mathrm{~b}$ & $3.50 \mathrm{~b}$ & $2.85 c$ & $1.78 \mathrm{~b}$ \\
\hline 349 & $1.55 \mathrm{~b}$ & $0.62 a$ & $0.33 c$ & $0.38 \mathrm{~b}$ & $3.49 \mathrm{~b}$ & $2.86 \mathrm{C}$ & $1.86 \mathrm{~b}$ \\
\hline 352 & $0.86 d$ & $0.27 c$ & $0.20 \mathrm{~d}$ & $0.26 c$ & $1.17 \mathrm{C}$ & $1.97 \mathrm{~d}$ & $1.35 \mathrm{C}$ \\
\hline 355 & $1.39 \mathrm{~b}$ & $0.39 \mathrm{~b}$ & $0.32 c$ & $0.57 a$ & $1.29 \mathrm{C}$ & $4.74 \mathrm{a}$ & $0.66 \mathrm{e}$ \\
\hline 356 & $1.30 \mathrm{c}$ & $0.40 \mathrm{~b}$ & $0.31 \mathrm{c}$ & $0.50 a$ & $0.31 \mathrm{c}$ & $0.74 f$ & $0.75 \mathrm{e}$ \\
\hline 357 & $1.05 \mathrm{~d}$ & $0.40 \mathrm{~b}$ & $0.27 \mathrm{c}$ & $0.33 \mathrm{c}$ & $0.17 c$ & $1.74 \mathrm{~d}$ & $0.37 \mathrm{f}$ \\
\hline accessions & sfd & pl & $\mathrm{pt}$ & pll & nsf & fm & dmc \\
\hline 346 & $1.21 \mathrm{a}$ & $2.12 \mathrm{~b}$ & $0.23 a$ & $2.98 \mathrm{a}$ & $68.40 \mathrm{a}$ & $5.90 \mathrm{a}$ & $15.22 \mathrm{C}$ \\
\hline 347 & $0.75 \mathrm{~b}$ & $1.55 \mathrm{~d}$ & $0.14 \mathrm{~b}$ & $0.73 d$ & $36.93 \mathrm{c}$ & $0.48 d$ & $17.73 \mathrm{~b}$ \\
\hline 348 & $1.18 \mathrm{a}$ & $2.14 \mathrm{~b}$ & $0.20 a$ & $1.65 \mathrm{~b}$ & $44.80 \mathrm{~b}$ & $2.94 \mathrm{~b}$ & $13.09 \mathrm{C}$ \\
\hline 349 & $1.18 \mathrm{a}$ & $2.09 \mathrm{~b}$ & $0.21 \mathrm{a}$ & $1.79 \mathrm{~b}$ & $29.34 \mathrm{C}$ & $3.03 \mathrm{~b}$ & $15.37 \mathrm{C}$ \\
\hline 352 & $0.84 \mathrm{~b}$ & $1.72 \mathrm{C}$ & $0.23 a$ & $1.01 \mathrm{C}$ & $25.07 \mathrm{c}$ & $0.89 c$ & $19.13 \mathrm{~b}$ \\
\hline 355 & $0.37 c$ & $2.38 a$ & $0.12 b$ & $2.98 a$ & $31.53 c$ & $1.04 \mathrm{c}$ & $19.55 \mathrm{~b}$ \\
\hline 356 & $0.66 \mathrm{~b}$ & $1.50 \mathrm{~d}$ & $0.08 \mathrm{c}$ & $0.62 \mathrm{~d}$ & $15.87 \mathrm{C}$ & $0.20 \mathrm{~d}$ & $13.96 \mathrm{C}$ \\
\hline 357 & $0.24 \mathrm{c}$ & $1.83 \mathrm{C}$ & $0.05 \mathrm{c}$ & $1.59 \mathrm{~b}$ & $17.50 \mathrm{c}$ & $0.12 d$ & $34.61 \mathrm{a}$ \\
\hline
\end{tabular}

The accession which presented higher plants was the 347, with mean of $36,12 \mathrm{~cm}$, and the accessions 348 and 349 were the ones which presented the lowest plants, with means of 16,28 and $18,48 \mathrm{~cm}$, respectively. According to Neitzke et al. (2010), medium to high-sized genotypes might be utilized for landscaping, in garden cultivations. Barroso et al. (2012) reported that pepper plants utilized for ornamental purposes ought to maintain the harmony between the plant architecture and the pot size, thus recommending the utilization of plants with height from 1,5 to 2 times the vase size. According to Rêgo et al. (2009a), the development of a new cultivar with harmonic and good-sized plants is one of the main objectives of any breeding program of ornamental pepper. In this present study the vase height utilized was $13 \mathrm{~cm}$. Except for the accessions 347 and 355, which presented relation between plant height and vase size higher than 2,0, and the accessions 348 and
349, which presented height lower than 1,5 times the vase height, all remaining accessions are appropriate for use as vase ornamental plants.

The accession 347 was the one which presented higher first bifurcation length, with mean of 17,14 cm. The accessions 348,349 and 346 were the ones which presented lower first bifurcation heights, with means of 5,26, 5,74 and $6,38 \mathrm{~cm}$, respectively. According to Barroso et al. (2012), only those pepper cultivars that reduce the size and the proportions might be commercialized as ornamental plants. There is no ideal first bifurcation height.

For the stem diameter, the accession that presented the highest mean was the 346 with value of $0,90 \mathrm{~cm}$, being recommended for utilization as ornamental, for avoiding the dumping off the plant. The remaining accessions presented means inferior to $0,71 \mathrm{~cm}$, not statistically differing within each other. This characteristic is important in the breeding of the 
pepper plants, since plants with very thin stems tend to lodge and thus lose its commercial value (Silva Neto et al., 2014).

The accession 346 was the one that presented the longer leaves, with mean of 6,76 $\mathrm{cm}$, the accessions 356 and 357 presented smaller leaves, with mean of 3,95 and $3,51 \mathrm{~cm}$. The length and width of the leaf are characteristics of great importance in the market of ornamental pepper plants, since that the leaves influence in the harmony of the canopy. For the leaf width, the accession 346 was the one that presented broader leaves, with mean of $3,53 \mathrm{~cm}$. Narrower leaves were presented by the accession 357, with mean of $1,29 \mathrm{~cm}$. With regard to the petiole length, the accessions with lowest means were the 348 and 352, with means of 1,37 and 1,30 $\mathrm{cm}$, respectively. The remaining accessions constituted the class with highest mean, varying from 2,73 to $1,81 \mathrm{~cm}$. Plants with smaller leaves and proportional to its canopy are the most desirable for ornamental purposes.

The accession 346 was the one that presented flowers with highest corolla length, with mean of $1,88 \mathrm{~cm}$. Highest petal diameter was observed in the accessions: 349, 346 and 348, with means of $0,62,0,59$ and 0,57 $\mathrm{cm}$, respectively, being recommended for utilization as ornamental plants. Larger flowers are interesting for providing beauty to the plant, since that the most attractive and pleasant are the plants to the eyes of the cosumer, the higher is the probability of sale.

As to the anther length, the accession with highest mean was the 346, with value of $0,45 \mathrm{~cm}$. Larger anthers are ideal for easing its removal during the performing of crossings without causing greater damages to the flower bud. The accessions 355, 346 and 356 presented flowers with largest filament, with means varying from 0,57 , to $0,50 \mathrm{~cm}$, respectively; the accessions that presented the smallest filaments were the 352, 347 and 357. Smaller filaments are desirable for decreasing the probability its fall when the breeder are performing the crossings.

The accession 346 was the one that presented the heaviest fruits, with mean of 6,89 $\mathrm{g}$, being adequate for the processing of sauces. The genotypes 357 and 356 where the ones that presented the lightest fruits, although not differing of the remaining within the same class. The accession that presented fruits with longer length was the 355 , with mean of $4,74 \mathrm{~cm}$. Large fruits may be commercialized, preferably in natura or dehydrated, whereas smaller fruits have the potential to be commercialized in industrialized sauces (Bento et al., 2007). The accession 356 was the one that presented lowest mean for this characteristic, with value of $0,74 \mathrm{~cm}$, being also recommended in the utilization as ornamental plants, for maintaining the equilibrium between the plant architecture and the fruit size. Rêgo et al. (2009b) emphasize the importance of the characteristics fruit length, largest fruit diameter and fresh matter as secondary components of production. According to these studies, it is possible to indirectly select the most productive plants by selecting these components.

For the largest fruit diameter, the accession that presented highest value was the 346 , with mean of $2,00 \mathrm{~cm}$. The genotype 357 was the one that presented the lowest value, with mean of $0,37 \mathrm{~cm}$. As to the lowest fruit diameter, the accessions with highest mean were the 346 , 348 and 349 , with means of 1,21, 1,18 and 1,18 $\mathrm{cm}$, respectively. The accessions 357 and 355 constituted the lowest mean class, with means of 0,24 and $0,37 \mathrm{~cm}$, respectively. Fruits with smaller dimensions are recommended for ornamental purposes, for maintaining the equilibrium with the plant architecture.

The accessions 356 and 347 were the ones that presented fruits with smallest pedicels, with means of 1,50 and $1,55 \mathrm{~cm}$. The highest pedicel length was observed in the accession 355 , with mean of $2,38 \mathrm{~cm}$, being adequate for ornamental purposes. Fruits with larger pedicel length contrasting with the leaves, being interesting for potted plants and floral arrangements (Melo et al., 2014).

The accessions 346, 352, 349 and 348 were the ones that presented fruits with thickest pericarp, with means varying from $0,23 \mathrm{~cm}$ to $0,20 \mathrm{~cm}$, being more adequate for commercialization, with the possibility to develop new pepper cultivars for ornamental purposes. Less thick pericarps were observed in the accessions 357 and 356, with means of 0,05 
and $0,08 \mathrm{~cm}$, respectively. Pericarp thickness is an important characteristic for the quality of fruits, both for fresh as for processed fruits (Rêgo et al., 2011). Lannes et al. (2007), in studies with $C$. chinense, reported a positive relation between the fruit weight and the thickness of the fruit wall, demonstrating the importance of this characteristic in the development of varieties for the market of fresh products, since that fruits with thicker pericarp are more resistant to damages in the post-harvest management and during transport.

The placenta length is a characteristic of extreme importance, since it is in the placenta that the most amount of capsaicin is located, an alkaloid responsible for the pungency of the fruits (Zewdie \& Bosland, 2001). The accessions 346 and 355 were the ones that presented the largest placentas, with mean of $2,98 \mathrm{~cm}$ for both. The 356 and 347 presented the lowest means for this characteristic, with values of 0,62 and $0,73 \mathrm{~cm}$.

The number of seeds per fruit is an important variable for determining the variability within the accessions, and it must be determined in characterization works (Bento et al., 2007). The accession 346 presented the highest number of seeds, with mean of 68,40 seeds per fruit, thus being the most indicated for utilization in breeding programs, for easing the propagation of the species, besides promoting the supply of the germplasm banks.

For the fresh matter, the accession 346 presented the highest mean, with value of 5,90 g. The accessions that presented lowest value of fresh matter were the 357, 356 and 347, with means varying from 0,12 to 0,48 $\mathrm{g}$.

The dry matter content is an important characteristic in the utilization of Capsicum for ornamental purposes, since that the higher is the dry matter content, the higher shall be the durability of the fruit in the plant. The accession 357 was the one that presented the highest dry matter content, with mean of 34,61 , being the most recommended for utilization as ornamental. The accessions 348, 356, 346 and 349, presented lowest value for this characteristic, with means of 13,09 to 15,37 .

According to Tocher's grouping method, based on the generalized Malahanobis distance, the accessions were reunited in two groups. In the first group are the accessions $348,349,352$, 347, 346 and 356, and in the second group are the accessions 355 and 357 (Table 3). The average distance within the groups is always smaller than the average distance between the groups, with more homogeneity occurring within the accessions of a same group than between accessions of different groups (Vasconcelos et al., 2007).

Table 3. Clustering of the parents by Tocher's method

\begin{tabular}{cc}
\hline group & accessions \\
\hline 1 & $348,349,352,347,346,356$ \\
2 & 355,357 \\
\hline
\end{tabular}

A similar result was observed by Rêgo et al. (2013) in an $F_{2}$ generation of Capsicum annuum, in which the 70 evaluated genotypes were reunited into two groups. Pessoa et al. (2015), evaluating 99 genotypes of $a F_{2}$ population of Capsicum annuum, described the formation of three distinct groups, thus demonstrating that the evaluated genotypes presented little divergence. Conversely, Bianchi et al. (2016), working with Capsicum, described the separation of the genotypes into eight distinct groups, resembling the observed by Silva Neto et al. (2014) and Barroso et al. (2012) in $F_{2}$ populations of Capsicum annuum. Rêgo et al. (2012b), also in studies with $\mathrm{F}_{2}$ generation of Capsicum annuum, described the formation of four distinct groups based on quantitative characters; however, when simultaneously evaluating the quantitative and qualitative characters, these authors observed the separation of the genotypes into seven groups, demonstrating the variability within genotypes and the possibility of its use in breeding programs.

In the analysis of the canonical variables, a phenotypic difference was detected in the analyzed accessions of Capsicum annuum, in which the three first variables explained $94,18 \%$ of the total variance (Table 4). Similar results were observed by Costa et al. (2016) in Capsicum, in which the three first canonical variables explained $99,97 \%$ of the total variance. Baba et al. (2016) in study of genetic diversity in Capsicum chinense, observed that the two first canonical variables explained $92,20 \%$ of the variability 
among the groups. This value suggests that the graphic representation of the two first canonical variables is appropriated for demonstrating the relation among the groups and the accessions within a same group.

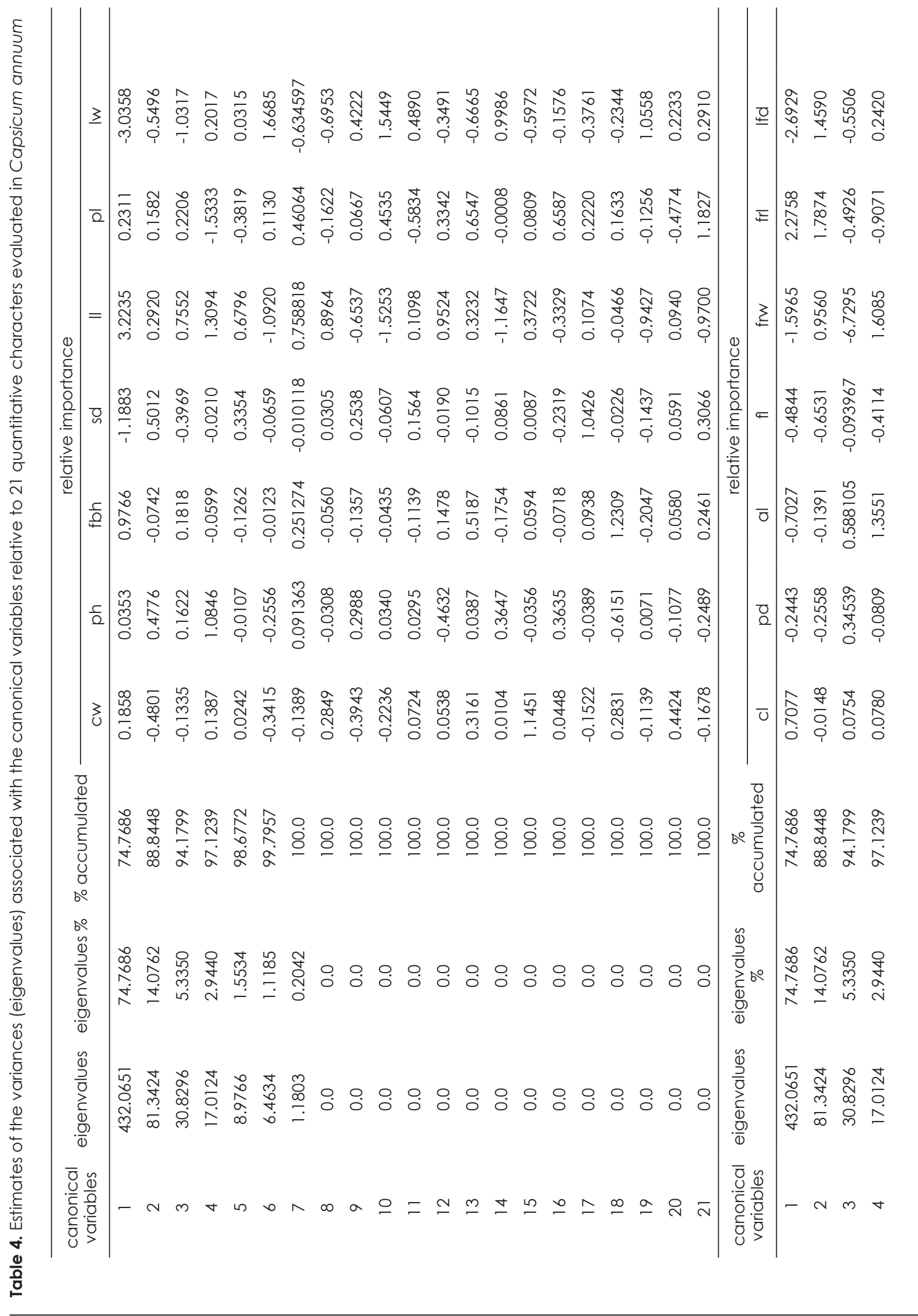




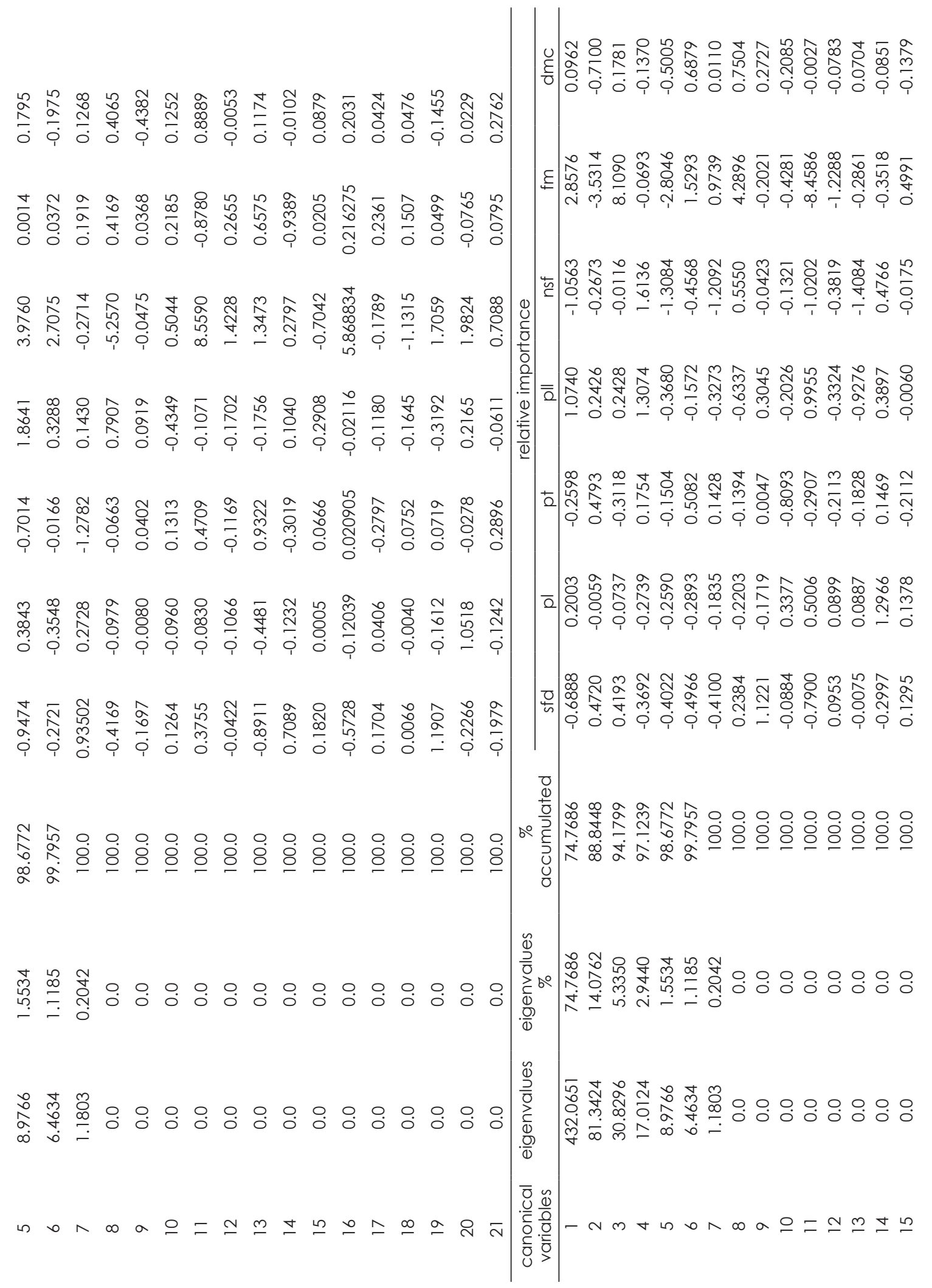




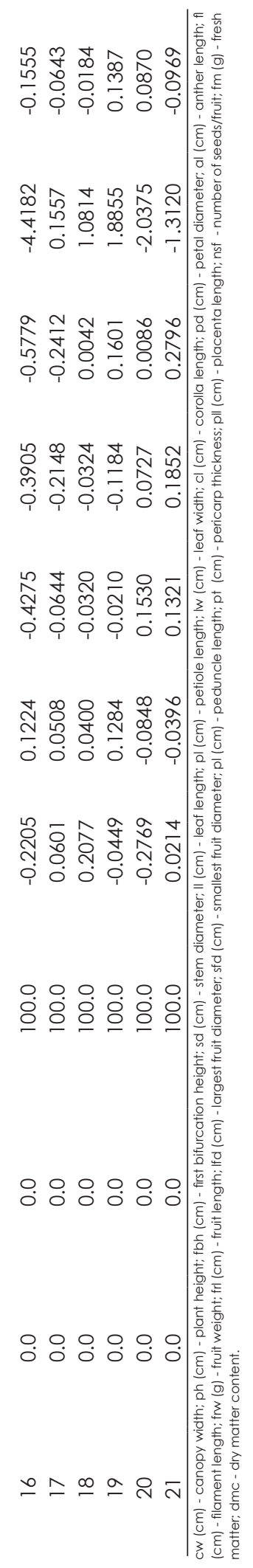

According to Bento et al. (2007), when the three first canonical variables explain more than $70 \%$ of the variation, the data fit a tridimensional graphic representation which allows the separation of the accessions in groups, and may me utilized as a strategy for selecting diverging genotypes. The variable fresh matter presented the highest eigenvector value in the last eigenvalue, thus being recommended the discard of this characteristic with base on the canonical variables.

According to the graphic dispersion, four distinct groups were formed (Figure 1). The first group was constituted by the genotypes 347, 348, 349,352 and 356 , the second group was composed by the genotype 346 , the third by the accession 357 and the fourth group by the accession 355 . The groups formed through graphic dispersion of the scores differed of the groups formed by Tocher's method, allowing the separation of the genotypes in a larger number of groups, with greater divergence within each other. In spite of the precision of Tocher's grouping method, since the individuals belonging to the same group are more homogenous than individuals belonging to different groups, the graphic dispersion based on the canonical variables may also be utilized for separating the genotypes in groups, since the two first canonical variables explained $90,5 \%$ of the variability among the groups.

Through Singh's method (1981), utilized for evaluating the relative importance of twenty-one quantitative characteristics, it was determined that the largest fruit diameter, fruit length and placenta length contributed with $68,43 \%$ of the genetic divergence, whereas the remaining contributed with only $31,57 \%$ (Table 5). The variable that most contributed with the divergence was the largest fruit diameter, with $31,39 \%$, and the ones that contributed less were the corolla length $(0,0159 \%)$, leaf length $(0,0330 \%)$ and canopy width $(0,0470 \%)$. Simillar result was observed by Bianchi et al. (2016), in which the variable that most contributed for the divergence was the fruit diameter, with $20,19 \%$, and the variable that less contributed was the leaf length, with only $2,68 \%$. In future divergence studies, the corolla length, leaf length and canopy width may be discarded, since according to Rêgo 


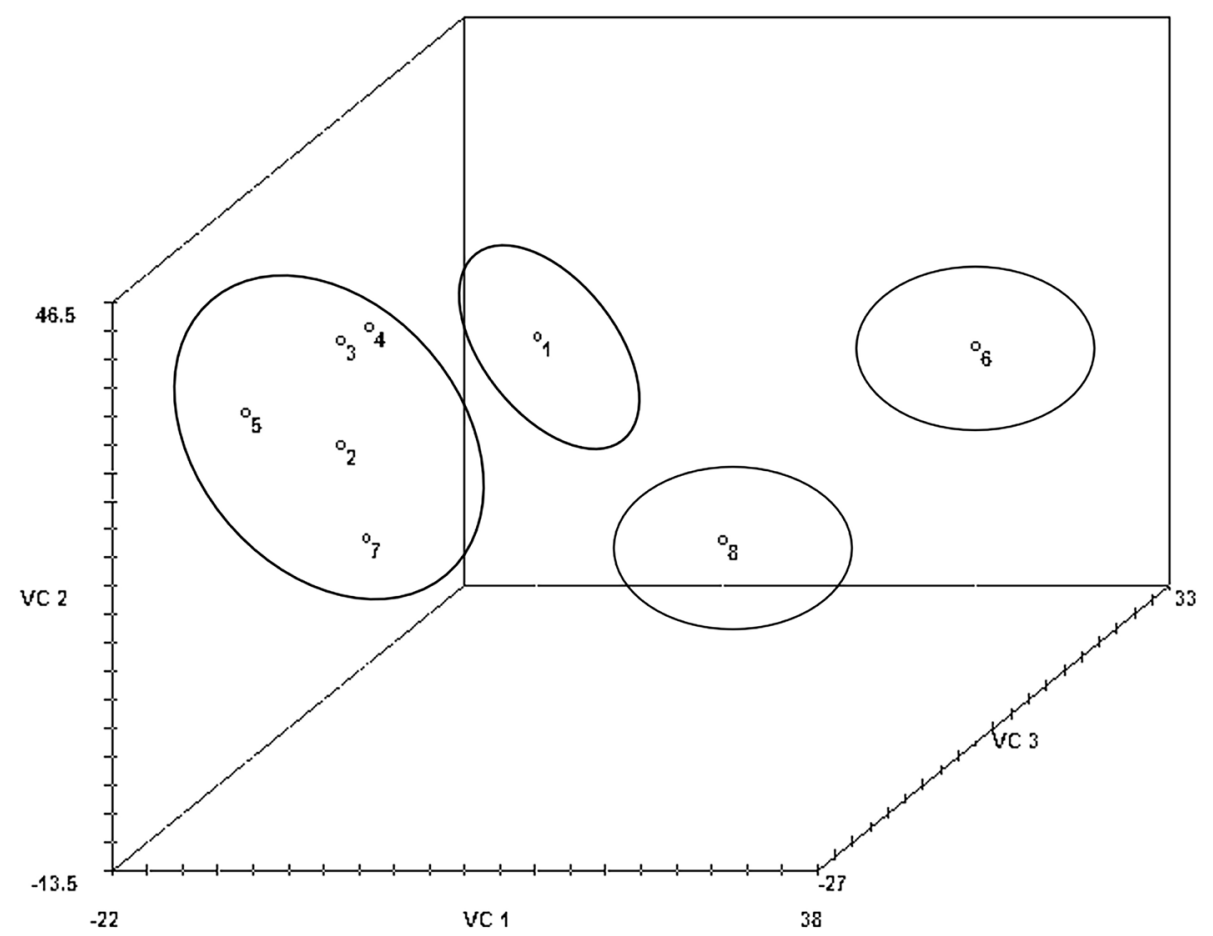

accessions

1. 346

2. 347

3. 348

4. 349

5. 352

6. 355

7. 356

8. 357

Figure 1. Scatter plot of 8 accessions of Capsicum annuum, considering the first three canonical variables

et al. (2003) characters that contributed with a very low percentage, or did not contribute to the detected variability, may be discarded.

Table 5. Relative contribution of quantitative characteristics of major importance to the genetic divergence of Capsicum annuum, by the method proposed by Singh (1981), based on the generalized distance of Mahalanobis

\begin{tabular}{|c|c|c|}
\hline variable & s.j & value in \% \\
\hline Ifd & 11963.3336 & 31.3901 \\
\hline $\mathrm{frl}$ & 10623.8460 & 27.8755 \\
\hline pll & 358.2953 & 9.1624 \\
\hline frw & 2451.8050 & 6.4332 \\
\hline IW & 2425.1326 & 6.3632 \\
\hline sfd & 2299.156881 & 6.0327 \\
\hline pt & 17.8995 & 2.5384 \\
\hline $\mathrm{fm}$ & 115.1944 & 2.6416 \\
\hline$d m c$ & 12.5889 & 1.814 \\
\hline ph & 358.2953 & 0.94 \\
\hline $\mathrm{Cl}$ & 323.1623 & 0.8479 \\
\hline fl & 304.0097 & 0.7977 \\
\hline $\mathrm{fbh}$ & 263.4719 & 0.69 \\
\hline al & 258.8589 & 0.6792 \\
\hline nsf & 263.4719 & 0.6644 \\
\hline $\mathrm{pd}$ & 188.9991 & 0.4959 \\
\hline sd & 115.1944 & 0.30 \\
\hline $\mathrm{pl}$ & 89.2412 & 0.2342 \\
\hline $\mathrm{CW}$ & 17.8995 & 0.047 \\
\hline$\|$ & 12.58893 & 0.0330 \\
\hline $\mathrm{Cl}$ & 6.0752 & 0.0159 \\
\hline
\end{tabular}




\section{Conclusions}

The eight analyzed accessions of Capsicum annuum were divergent, presenting genetic variability, and present potential for being utilized as parents in breeding programs or ornamental pepper plants.

\section{Referências}

Baba, V.Y., Rocha, K.R., Gomes, G.P., Ruas, C. de F., Ruas, P.M., Rodrigues, R., Gonçalves, L.S.A. 2016. Genetic diversity of Capsicum chinense accessions based on fruit morphological characterization and AFLP markers. Genetics Resources and Crop Evolution 63 (8): 1371-1381.

Barroso, P.A., Rêgo, E.R., Rêgo, M.M., Nascimento, K.S., Nascimento, N.F.F., Nascimento, M.F., Soares, W.S., Ferreira, K.T.C., Otoni, W.C. 2012. Analysis of Segregating Generation for Components of Seedling and Plant Height of Pepper (Capsicum annuum L.) for Medicinal and Ornamental Purposes. Acta Horticulturae 953: 269-276.

Bento, C.S., Sudré, C.P., Rodrigues, R., Riva, E.M., Pereira, M.G. 2007. Descritores qualitativos e multicategóricos na estimativa da variabilidade fenotípica entre acessos de pimenta. Scientia Agraria 8: 149-156.

Bianchi, P.A., Dutra, I.P., Moulin, M. M., Santos, J.O., Santos Júnior, A.C. 2016. Morphological characterization and analysis of genetic variability among pepper accessions. Ciência Rural 46 (7): 1151-1157.

Costa, F.R., Pereira, T.N.S, Sudré, C.P., Rodrigues, R. 2009. Marcadores RAPD e caracteres morfoagronômicos na determinação da diversidade genética entre acessos de pimentas e pimentões. Ciência Rural 39 (3): 696-704.

Costa, L.V., Bentes, J.L.S., Lopes, M.T.G., Alves, S.R.M., Viana Júnior, J.M. 2015. Caracterização de acessos de pimentas do Amazonas. Horticultura Brasileira 33: 290-298.

Costa, M.P.S.D., Rêgo, M.M., Silva, A.P.G., Rêgo, E.R., Barroso, P.A. 2016. Characterization and genetic diversity of pepper (Capsicum spp) parents and interspecific hybrids. Genetics and Molecular Research 15 (1): 1- 12.
CRUZ, C.D. 2006. Programa Genes: aplicativo computacional em genética e estatística. UFV, Viçosa, Brasil. CD-ROM

Faria, P.N., Cecon, P.R., Silva, A.R., Finger, F.L., Silva, F.F., Cruz, C.D., Sávio, F.L. 2012. Métodos de agrupamento em estudo de divergência genética de pimentas. Horticultura Brasileira 30 : 428-432.

Ferrão, L.F.V., Cecon, P.R., Finger, F.L., Silva, F.F., Puiatti, M. 2011. Divergência genética entre genótipos de pimenta com base em caracteres morfoagrônomicos. Horticultura Brasileira 29: 354358.

Ferraz, R.M., Ragassi, C.F., Heinrich, A.G., Lima, M.F., Peixoto, J.R., Reifschneider, F.J.B. 2016. Caracterização morfoagronômica preliminar de acessos de pimentas cumari. Horticultura Brasileira 34: 498-506.

Gonçalves, L.S.A., Rodrigues, R., Amaral, A.T.J.R, Karasawa, M., Sudré, C.P. 2008. Comparison of multivariate statistical algorithms to cluster tomato heirloom accessions. Genetics and Molecular Research 7: 1289-1297.

INTERNATIONAL PLANT GENETIC RESOURCES INSTITUTE. IPGRI. 1995. Descriptors for capsicum. IBPGRI, Rome, Italy. 49 p.

Silva, W.C., Carvalho, S.I.C., Duarte, J.B. 2013. Identification of minimum descriptors for characterization of Capsicum spp. germplasm. Horticultura Brasileira 31: 190-202.

Lannes, S.D., Finger, F.L., Schuelter, D.R., Casali, V.W.D. 2007. Growth and quality of Brazilian accessions of Capsicum chinense fruits. Scientia Horticulturae 112: 266-270.

Laurentin, H. 2009. Data analysis for molecular characterization of plant genetic resources. Genetic Resources and Crop Evolution 56: $277-$ 292.

Melo, L.F. de, Gomes, R.L.F., Silva, V.B. da, Monteiro, E.R., Lopes, A. C. A., Peron, A.P. 2014. Potencial ornamental de acessos de pimenta. Ciência Rural 44 (11): 2010-2015.

Neitzke, R.S., Fischer, S.Z., Vasconcelos, C.S., Barbieri, R.L., Treptow, R.O. 2016. Pimentas 
ornamentais: aceitação e preferências do público consumidor. Horticultura Brasileira 34: 102-109.

Neitzke, R.S., Barbieri, R.L., Rodrigues, W.F., Corrêa, I.V., Carvalho, F.I.F. 2010. Dissimilaridade genética entre acessos de pimenta com potencial ornamental. Horticultura Brasileira 28: 47-53.

Pessoa, A.M. dos S., Rêgo, E.R., Barroso, P.A., Rêgo, M.M. 2015. Genetic Diversity and Importance of Morpho-Agronomic Traits in a Segregating $\mathrm{F}_{2}$ Population of Ornamental Pepper. Acta Horticulturae. 1087: 195-200.

Pickersgill, B. 1997. Genetic resources and breeding of Capsicum spp. Euphytica 96: 129133.

Rêgo, E.R., Rêgo, M.M., Cruz, C.D., Cecon, P.R., Amaral, D.S.S.L., Finger, F.L. 2003. Genetic diversity analysis of peppers: a comparison of discarding variable methods. Crop Breeding and Applied Biotechnology 3(1): 19-26.

Rêgo, E.R., Rêgo, M.M., Silva, D.F., Cortez, R.M., Sapucay, M.J.L.C., Silva, D.R., Silva Junior, S.J. 2009a. Selection For Leaf And Plant Size And Longevity Of Ornamental Peppers (Capsicum spp.) Grown In Greenhouse Condition. Acta Horticulturae 829: 371-375.

Rêgo, E.R., Rego, M.M., Finger, F.L., Cruz, C.D., Casali, V.W.D. 2009b. A diallel study of yield components and fruit quality in chilli pepper (Capsicum baccatum). Euphytica 168: 275-287.

Rêgo, E.R., Rêgo, M.M., Cruz, C.D., Finger, F.L., Casali, V.W.D. 2011. Phenotypic diversity, correlation and importance of variables for fruit quality and yield traits in Brazilian peppers (Capsicum baccatum). Genetic Resources and Crop Evolution 58 (6): 909-918.

Rêgo, E.R., Nascimento, M.F., Nascimento, N.F.F., Santos, R.M.C., Fortunato, F.L.G., Rêgo, M.M. 2012a. Testing methods for producing self-pollinated fruits in ornamental peppers. Horticultura Brasileira 30: 669-672.

Rêgo, E.R., Santos, R.M.C., Rêgo, M.M., Nascimento, N.F.F., Nascimento, M.F., Bairral,
M.A. 2012b. Quantitative and Multicategoric Descriptors for Phenotypic Variability in a Segregating Generation of Ornamental Peppers. Acta Horticulturae 937: 289-296.

Rêgo, E.R., Rêgo, M.M., Finger, F.L., Nascimento, N.F.F., Nascimento, M.F., Santos, R.M.C. 2013. Phenotypic variability and importance of characters in a F2 segregating generation of ornamental Chili (Capsicum annuum). Acta Horticulturae 1000: 493-497.

Rêgo, E.R., Rêgo, M.M., Finger, F.L. 2015. Methodological basis and advances for ornamental pepper breeding program in Brazil. Acta Horticulturae 1087: 309-314.

Rêgo, E.R., Rêgo, M.M. 2016. Genetics and breeding of chili pepper Capsicum spp. In: Rêgo, E.R., Rêgo, M.M. Finger, F.L. (eds) Production and breeding of chili peppers (Capsicum spp.). Spring International Publishing, Cham. p. 1-129.

Rêgo, E.R., Rêgo, M.M. 2018. Ornamental pepper. In: Van Huylenbroeck, J. Ornamental crops. Spring International Publishing, Switzerland (in press).

Silva, A.R., Cecon, P.R., Rêgo, E.R., Nascimento, M. 2011. Avaliação do coeficiente de variação experimental para caracteres de frutos de pimenteiras. Revista Ceres 58 (2): 168-171.

Silva Neto, J.J., Rêgo, E.R., Nascimento, M.F., Silva Filho, V.A.L., Almeida Neto, J.X., Rêgo, M.M. 2014. Variabilidade em população base de pimenteiras ornamentais (Capsicum annuum L.). Revista Ceres 61 (1): 84-89.

Singh, D. 1981. The relative importance of characters affecting genetic divergence. Indian Journal of Genetics and Plant Breeding 41 (1): 237-245.

Vasconcelos, E.S., Cruz, C.D., Bhering, L.L., Resende Júnior, M.F.R. 2007. Método alternativo para análise de agrupamento. Pesquisa Agropecuária Brasileira 42 (10): 1421-1428.

Zewdie, Y., Bosland, P. 2001. Combining ability and heterosis for capsaicinoids in Capsicum pubescens. Horticultural Science. 36 (7): 13151317. 